\title{
A Political Scientist in the Reference Library ${ }^{1}$
}

Dr. Lewis is associate professor of political science, University of Illinois.

$\mathrm{P}^{\circ}$ olitics is a study of man in his relationship to other men, especially in connection with the keeping of order by the device called the state. Although we speak of the study of politics as political science, there is considerable difference of opinion among political scientists as to whether their scholarly discipline has actually reached the status of a science. Some say that the discipline is so young that it now has reached only the elementary descriptive stage, but not the rule-making stage. These people hold that while we are now able to describe more or less accurately what happened, we are not yet able to make rules that can be applied to forecast behavior.

Whether political science is as yet a fullfledged science or a science-in-the-making does not affect the fact that the reference library is the laboratory of the political scientist. It is the storehouse of the experiences of men. The political scientist can, of course, collect some material firsthand by watching politics in action, but the library stacks contain a vastly greater collection of recorded political experience than one political scientist could ever see for himself in a lifetime. The reference library is the chief source of the raw material essential for his political analysis.

As he analyzes his raw material, the political scientist realizes that his problems

1 Paper presented at meeting of Reference Section, 1 Paper presented at meeting of Reference Section,
ACRL, Chicago, Jan. 27, r950; revised April r95 1 . often have two aspects. One of these aspects is scientific, but the other, paradoxically, is philosophical. Part of his problem is to find out what the actual facts are so that he can discover how they fit into patterns, and how these patterns can be used to explain rules of political behavior or possibly to forecast future political behavior or trends. Sometimes, though, the political scientist is also greatly concerned with value judgments, the province of the philosopher. This aspect of his problem is involved when he questions what the proper objectives of the state should be. For example, should the state control economic life? Or, to be more specific, should the government require coal miners to mine coal if they do not wish to mine it? Or should government antitrust lawyers bring suit to break up huge food store chains? Such questions are the essence of politics and many political scientists try to say which is the better solution rather than satisfying themselves by describing the possible consequences of government action. The library has a vital role in this matter of value judgments because the library contains the works of the political philosophers of the past and present, the men who have speculated on what governments ought properly to do.

In his search for facts and theories, how much assistance can the political scientist reasonably expect to receive from the reference librarian? The answer to this question depends on the academic level of the political scientist. If he is a beginner, he will necessarily lean heavily on the biblio- 
graphical help which the reference librarian can provide. At this stage the reference librarian is more teacher than librarian. The beginner may not know of even such elementary sources as the U.S. Government Manual or the various encyclopedias. His questions are apt to be general and broad rather than detailed and specific. The librarian will probably introduce him to the standard bibliographical aids - to the Bulletin of the Public Affairs Information Service, the International Index, and the Readers' Guide to Periodical Literature. She will remind him of the Statesman's Yearbook and perhaps the Book of the States. Once the librarian has helped the beginner become acquainted with these and other standard aids, the student should not expect help in locating material that can be found in these compilations.

But what kind of assistance will the more experienced instructor hope to receive? His questions are likely to be about small factual details. He knows, of course, where to find the major pieces of information. $\mathrm{He}$ has probably worked out the general aspect of his problem and has done an extensive amount of digging for facts before turning to the reference librarian for aid. $\mathrm{He}$ is looking for the elusive detail, the sort of detail that can almost never be found in the obvious place, perhaps because the periodical that contains it is in the bindery, or perhaps because the appropriate work is not in translation, or for a variety of other reasons.

Before the professor asks the reference librarian for assistance he has probably searched his own files. My own personal files include a great volume of clippings from the New York Times. Daily reading of the New York Times has been a must for me ever since I began teaching. The one drawback to a vacation is the tremendous accumulation of Times waiting my return. From it I clip copies of foreign con- stitutions and all sorts of odds and ends about legislation, both national and foreign. It takes a considerable time for even our own laws to become available after they have been passed. As for foreign documents, those that do come to a library are often slow in arriving and many are never received at all.

In addition to my clippings, I have boxes of bibliography cards. These I have compiled from the library books I have used, the book reviews and bibliographies of the $\mathrm{Am}$ erican Political Science Review, from the New York Times daily list of published works, from book advertisements that I receive, and from suggestions given to me by colleagues and others. Then I keep a factual file, in which facts such as the operations of the English National Coal Board are collected. I have, also, a number of miscellaneous facts recorded in old lecture notes, and various random jottings from general reading.

Before asking help of a reference librarian in my search for an elusive detail, I first comb through my own files and library, and through the professional journals. After that I work over the library's card index, the various guides, document catalogs, newspaper indexes, and bibliographical lists known to me. It is a redletter day when I learn of a new source of material, such as the International Press Correspondence.

At the time I stumbled on this source of information I was hunting unemployment figures for Russia. All of us know, of course, that unemployment is something which Russia claims she does not have. One of the chief selling points for her brand of government is that there is work for all. Back in the mid-twenties, however, before the five-year plans got underway, there was a considerable amount of unemployment among Russia's industrial workers. I 
wanted the actual figures for my class work. I had references to speeches presented to the Communist party congresses, but the reports I needed were not available in English translation. On a chance I tried the International Press Correspondence, which I found cataloged in the library shelf list under "Communism, periodicals." It proved to be a veritable mine of information about the official Communist party line on a variety of subjects, and $I$ find it a matter of great regret that it suffered a drastic change in content in 1938 that almost nullified its usefulness for my work as far as anything published since that year is concerned.

After exhausting all other easily available sources of information, I usually explore the stacks before questioning the reference librarian. Here chance plays an important role-chance, and the cataloging department of the library. An example of the sort of thing that can happen has to do with my attempt to learn the exact definition of a kulak. Webster defines a kulak as a "rich peasant; esp., a prosperous farmer who has made money out of the poorer class," etc. That is an adequate definition for those interested in general literature, but when a political scientist learns that the Russian government is confiscating the lands of the kulaks, he wants a more explicit definition. Wealth is a very comparative thing and the definition of "rich" is highly elastic.

My search for the definition of kulak led me to the works of two reputable authors, both of whom defined a kulak in terms of the number of acres he owned. The difficulty was that they did not agree on the amount. I looked through the available works on agriculture as it existed in Tsarist days and found various definitions of kulaks based on other considerations of land owned. In a Russian-English dictionary I found that a kulak was a forestaller. A Russian forestaller, incidentally, was a man, usually a peasant farmer, who bought up the crops of others at harvest time and resold them later at great profit.

In the selected works of Lenin - and by the way I found these cataloged next to the works of Jefferson and close to the works of Washington under the writings of political theorists-I found a definition of rich farmer based on land owned, but not a specific number of acres. Lenin, like many other writers, classified farmers as poor, middle and rich. I assumed that Lenin's rich farmers were kulaks, but I did not find a Russian version of his writings in which I could check this point. Then I looked in Stalin's writings, and quickly found references to books that were not in the library. Thereupon I gave up for the time being. Later, while looking through the Russian Economic Notes of the U.S. Department of Commerce for something else, I stumbled on a Russian decree defining a kulak. A recent clipping from the Christian Science Monitor on collectivization of agriculture in Latvia, Estonia and Lithuania used substantially the same definition as that of the earlier Russian decree.

After exhausting all other sources of information, I commonly turn to the reference librarian, looking for fresh leads. It is amazing how often these leads are given to me, considering the fact that the reference librarian must be informed not only about political science, but about literature, natural sciences, and a vast number of other learned disciplines.

Some time ago, after a most exhaustive search, I asked the reference librarian if she could suggest any place where I might \ find the constitutions of the Russian satellite states. The general descriptions of these constitutions had been in the New

(Continued on page I62) 
is priced at 5s. (3s. 6d. to members). The Association has also released The Year's Work in Librarianship, vol. XIV, 1947 (195 I, 337p.) edited by W. A. Munford. As with previous volumes in this series, an effort is made to cover a variety of aspects of librarianship as revealed in both English and other professional journals. Since the material covers the year 1947 (the volume having been interrupted by World War II), the material may not be as fresh to readers as the editor and writers would like. However, it serves a useful purpose in bringing together observations on the accomplishments and literature of the year in question. (30s.-22s. 6d. to members).

The first number of News Sheet has been issued by the newly organized Pure and Applied Sciences Section of ACRL. This publication will contain information of interest to all members of this new section.

Uranium and Its Compounds; a Bibliography of Unclassified Literature compiled by Fred E. Croxton, Oak Ridge, Tenn., Carbide and Carbon Chemical Company 195I, Report No. K-295, part 2, includes three thousand nine hundred and seventy references to the unclassified literature on uranium published between 1789 and 1950. Author, subject and report or patent number indexes to the chronological record are included, and brief annotations or abstracts given for most of the items.
The Special Libraries Association has issued a new Directory of Members (as of March Io, 195I), including almost five thousand names, 296p. \$4.oo.

The Special Libraries Council of Philadelphia and Vicinity has published a Directory of Libraries and Information Sources in the Philadelphia Area, edited by Mrs. Rebecca B. Monego (1951, 128p., \$2.25, order from Mrs. Monego, 5I E. Garfield St., Philadelphia 44, Pa.)

Author Headings for the Official Publications of the State of Wyoming (American Library Association, 1951, 60p., $\$ 1.50)$ is another in the list of such compilations of state author entries. It is a useful tool for catalogers.

The Theodosian Code and Novels and the Sirmondian Constitutions, a translation with commentary, glossary, and bibliography, by Clyde Pharr, in collaboration with Theresa Sherrer Davidson and Mary Brown Pharr (Princeton University Press, 1952, 643p., \$20.00) is volume I of The Corpus of Roman Law (Corpus Juris Romani). This work is intended to be a translation, with commentary, of all the source material of Roman law. The Theodosian Code contains laws which are similar to those involving modern problems of society-price fixing, black markets, socialized medicine, state controls, etc. It should serve as a useful reference source for workers in the social sciences generally.

\section{A Political Scientist in the Reference Library}

\section{(Continued from page 143)}

York Times and I had found descriptions of them in various other places, but I wanted the constitutions themselves. She said, "Have you looked in the United Nations Yearbook on Human Rights for 1947?" I had not looked there. When I did, I found sections of the various constitutions that dealt with human rights. Much more important, however, there were footnotes acknowledging information on constitutions from legations and embassies of satellite countries-the sort of information that made it possible for me to write for copies of the various constitutions.
Since that time, this material has been conveniently presented in Amos J. Peaslee's Constitutions of the Nations.

Judging from my own experiences, I feel that the political scientist of some experience does not expect from the reference librarian help on the body of the material, but on the all important and often incredibly elusive peripheral details. He hopes for information about the newer bibliographies that he has not yet met, and for leads in outside fields-leads that will take him to the amazingly concealed facts which his own research would not uncover. 